\title{
The revitalization of Mak Yong in the Malay world
}

\author{
PUDENTIA MPSS
}

\begin{abstract}
Culture can only be revitalized when a cultural tradition is considered of significant importance by its owning community. How important it is for the identity of that community or to what extent it symbolizes that community can only be established after in-depth study. It is crucial that revitalization activities involve the community. If not, efforts would be pointless. Mak Yong is one of the Malay performing art traditions that has been revitalized over the last five years. It is an art form that originates in southern Thailand and was brought to Bintan in the Riau Islands (Kepulauan Riau, Kepri) via Singapore. It combines dialogue, dance, singing, music, and stories and may still be found in the Riau Islands in Indonesia. It is interesting to show how Mak Yong has represented and expressed Malay dynamics by means of revitalizations efforts.

KEYWORDS

Oral Tradition Revitalization, Mak Yong, Riau Islands, Malay world.
\end{abstract}

\section{INTRODUCTION $^{1}$}

Mak Yong is an oral performing art tradition that may still be encountered in the Riau Islands (Kepri) and more specifically in the islands of Batam and Bintan. In Batam, Mak Yong is performed by a group from Pulau Panjang. In Bintan it is still found in two places, Kampung Keke, Kecamatan Kijang, and Pulau Mantang Arang, an island off the coast of East Bintan. In both places, the performers of Mak Yong belong to the third and fourth generations after the founders of the Mak Yong groups. to English.

I would like to thank Dick van der Meij for his translation of my article from Indonesian

PUDENTIA MPSS is a head lecturer at the Indonesian Studies Programme at the Faculty of Cultural Sciences, University of Indonesia. She is also the chair of the Oral Traditions Association and member of the Indonesian Eminent Persons Group Indonesia-Malaysia. She wrote her PhD on the Mak Yong Theater in Riau Islands, and is active in the field of Malay Studies. At present she prepares a proposal with Dr. Dick van der Meij for the inclusion of Mak Yong in the UNESCO Memory of the World Programme. Pudentia MPSS may be contacted at: pudentia_mpss@yahoo.com.

(C) 2010 Faculty of Humanities, University of Indonesia 
Mak Yong consists of a ritual and an entertainment component and combines dialogue, dance, singing, music, and stories in its performances. A performance is invariably preceded by an opening ritual called buka tanah (opening of the soil) and a performance closes with a similar ritual entitled tutup tanah (closing of the soil). Mak Yong is a traditional oral performing art form, which means that performers and the public together gather in the same place and at the same time during a performance. There is thus no clear divide between the performers and the audience as in the case of written traditions; in a way, they create the art form in a combination between the performer and the audience as both react to each other. The performers consist of musicians (some of whom also perform in dramatic roles), players who enact the story and engage in dialogue, singing, and dancing, and a choirlike group of performers who sit on the ground and join in the singing. The musical instruments consist of one two-string violin (rebab), a flute (serunai), a lead drum (gendang pengibu), accompanying drums (gendang penganak), a lead tambourine (gedombak pengibu, actually a kind of small drum closed by a bide on one side only), an accompanying tambourine (gedombak penganak), a gong, various small gongs (kenong, small gong made of bronze and played by hitting it with a stick). Sometimes a kecrek, an instrument made of a split bamboo of about $45 \mathrm{~cm}$ in length and $6 \mathrm{~cm}$ in width is added. Illustration 1 shows the following instruments: gedombak, gendang, gong, and kenong. During the play some characters wear masks (Illustration 2), but not everyone. Especially men who perform the roles of females wear masks but also ogres and other supernatural beings are portrayed by men who wear masks. A group usually has no more than 10 masks at most and they are usually made by a member of the group.

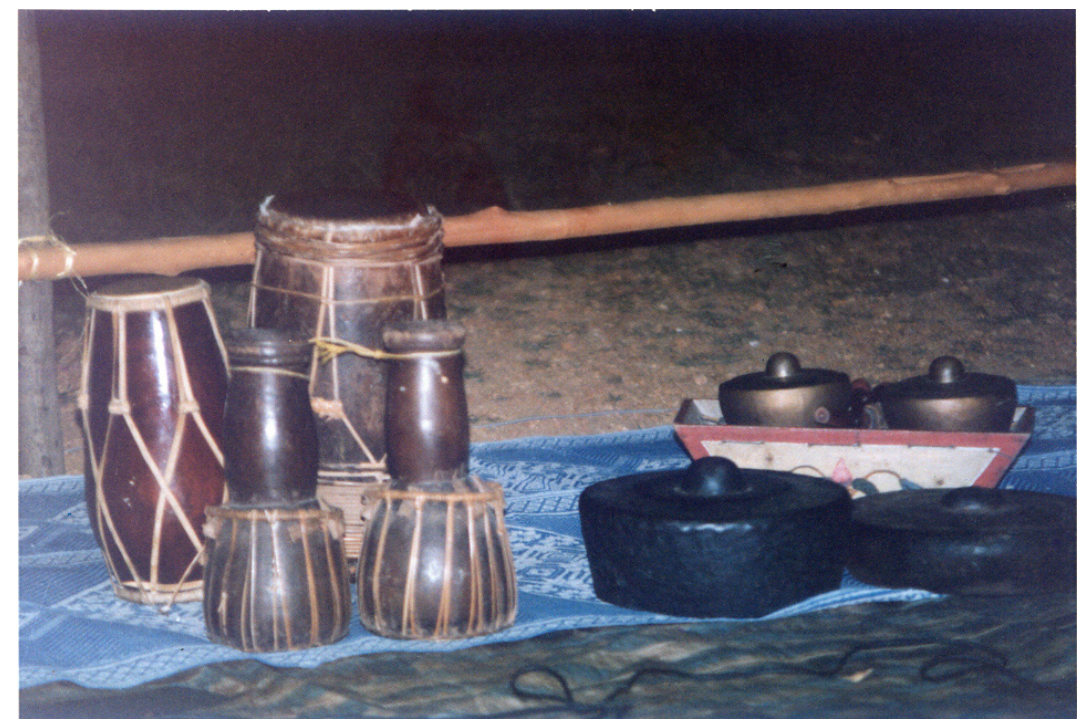

Illustration 1. Mak Yong instruments (a set of gendang, a set of gedombak, gong, and kenong); Photograph by the author, 1993. 


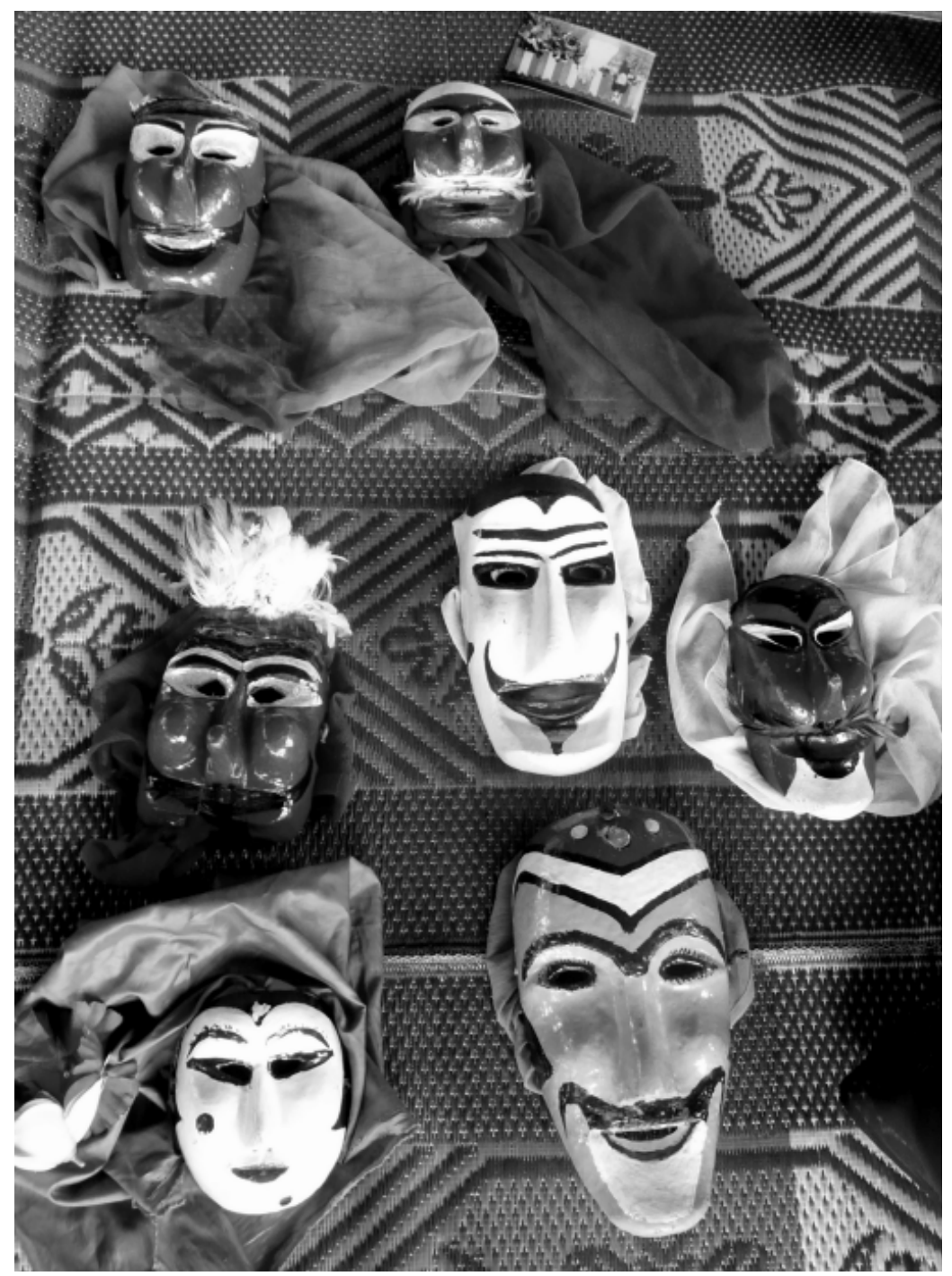

Illustration 2. The masks used by the Mak Yong group from Pulau Panjang; Photograph by Dick van der Meij, 2008.

\section{MAK YONG IN THREE COUNTRIES}

Up to the present, experts have been in disagreement over the exact meaning of the expression "Mak Yong". However, they do agree that Europeans first heard of its existence in Thailand (then Siam) in Nara Yala, Patani (Narathiwat) in the seventeenth century and that it had spread to Kelantan (Malaysia) around two hundred years ago. However, in Malaysia no masks were used as in the place of origin (Sheppard 1972: 58, 134; Suki 1978: 2; Ghulam-Sarwar 1982: 108; Sastrosuwondho 1985: 16). Mak Yong was brought to Kelantan for the first time as a present from Patani for a marriage between the two Sultanates of Patani and Kelantan (see Ghulam-Sarwar 1982). 
Although Mak Yong is still found in Batam and Bintan, its existence may be said to be kerakap tumbuh di batu in other words, "it still lives but is almost no longer there", or "it is said no longer to exist but is still around". In the words of Mak Yong players themselves hidup segan, mati tak mau, or "reluctant to live, unwilling to die". In Patani, Mak Yong is considered "too Malay" and therefore considered to diminish Thai identity. Contrarily, Muslims in Patani consider Mak Yong no part of their Malay Muslim culture and they have no wish for its existence. In Kelantan, Mak Yong is seen as not to reflect Islamic Malayness and was banned by Governor Nik Abdul Aziz Nik Mat (Akmar 1993). This is interesting as Mak Yong thrived in the early parts of the twentieth century under the protection of a Kelantan Prince, Abdul Ghaffar who, in 1923, even went as far as to build a special cultural village, named Kampung Temenggung, which was among others designed to develop Mak Yong.

Although Mak Yong is still around in Patani, it is no longer performed due to the unfavourable political situation because of which people who used to go back and forth from Patani to Kelantan and from Kelantan to Patani can no longer do so. Up to the present, the political situation in the region has been strained and we may say that Mak Yong is no longer alive there. It is also no longer vibrant because in Patani, as in Riau, it is a performance that used to be part of a tribute and is therefore different from the situation in Kelantan where it is also a form of medical treatment for patients who can no longer be cured through modern medical care. When used for medical purposes, the story entitled Main Putri is performed and because of this role in society, Mak Yong has more vibrancy in Kelantan notwithstanding the official prohibition.

Mak Yong in Kelantan expired after the Kelantan Prince died but resurfaced under the protection of Tan Sri Dato Nik Ahmed, the Governor of Kelantan and Member of Parliament in Malaysia. However, when he also passed away in December 1997, Mak Yong began its slow but steady demise. This being so, although seldom performed, Mak Yong in Malaysia may still be found in various places outside its region of origin such as Terengganu, Kedah, and in Kuala Lumpur and it is part of the teaching material in the Art Academy, also because it is still being used as part of a health care ceremony as mentioned above. Malaysian Mak Yong may be said to have reached the peak of its glory just recently when, in 2008, the government's proposal to have it included as a Masterpiece of Intangible Cultural Heritage was honoured by UNESCO. Since then, Mak Yong has been officially recognized in Malaysia as one of the symbols of Malay identity. Various photographs and posters featuring Mak Yong may invariably be encountered during cultural celebrations where Malaysia plays its part.

\section{MAK YONG IN THE RIAU ISLANDS}

Around one hundred years ago, Mak Yong was brought from Kelantan to the Riau Islands through Tanjung Kurau (present-day Singapore) by Mak Ungu and his group. To the present day, Mak Ungu is recognized as the pioneer of 
Riau Mak Yong. Interestingly, the Mak Yong that may now be encountered in Riau and which is said to originate from Kelantan uses masks as is the case in Patani but not in Kelantan itself. Also interesting is that although the titles of the stories that are performed in Patani, Kelantan, and in Riau are the same, the way they are performed differs in each region. The repertoire used is different in each region as well, but this is another subject and below I will no longer refer to Patani Mak Yong and to Kelantan Mak Yong only in connection with our discussion of Mak Yong as found in Riau.

Riau Mak Yong, as stated above, is still found in Batam (Pulau Panjang) and in Bintan (Keke and Pulau Mantang Arang). Batam Mak Yong is no longer complete and it is very difficult to organize a performance today by lack of players for specific roles and because of the incomplete set of musical instruments they have at their disposal. The repertoire is moreover also limited. None of the Mak Yong figures in this group is able to relate all the Mak Yong stories there once were, because, in contrast to Bintan, the players here are the third generation of performers and the collective memory needed for remembering the stories has faded. The group also does not have any documentation of previous performances. A positive point is that many youngsters, even young children join the group during performances. Unfortunately, because of the limited repertoire and the few occasions they have to witness performances, the training of these young players is insufficient. Because of these conditions, the rest of this article will no longer refer to this group.

The two Mak Yong groups in Bintan originate from the same source because Tuk Atan and Pak Khalid both inherited the art from Mak Ungu whom I mentioned above. Pak Khalid is from the second generation and trains the Mantang Arang Mak Yong group while his first cousin, Tuk Atan, trained the Keke Mak Yong group until his passing in 2006, when his son, Satar, took over as its leader assisted by his brother, Mohtar. Unfortunately, Mohtar is more interested in his job as a fisherman rather than being actively engaged in Mak Yong. Because of this, Satar often encounters problems because he has to play both instruments most important in Mak Yong, the gedombak and the gendang. When his brother is not available, he only features the lead and the accompanying gendang and is forced not to play the gedombak. The leading role, King/Cik Wang and the Queen (permaisuri) are no longer performed by players of the second or third generation, but by young people from the fourth generation, the direct or indirect grandchildren or even the nephews and nieces of Mak Wet, the prima donna of the second generation.

Although utmost important, the rebab is nowadays no longer played because Tuk Atan has passed away. A new rebab player has just started his training by using old recordings of Mak Yong performances. After Pak Senen passed away, the serunai is also no longer used during performances. Although both musical instruments are no longer used, Mak Yong performances may still be witnessed because there is still a complete group of performers and other supporting roles in Bintan. After Tuk Atan's death, the only player of 
the second generation at present still alive is Pak Khalid who now prefers to stay in Mantang Arang to teach Mak Yong. He is actually an actor but he also teaches music and song (see Illustration 3).

In Illustration 3 Pak Khalid is joined by Tuk Atan (with the black cap) and they used to teach alternatively although they often quarrelled because of differences of opinion. Tuk Atan is the oldest Riau Mak Yong figure and he likes to stay very close to the tradition he inherited from his predecessors while Pak Khalid is the oldest member of the Mantang Arang Mak Yong group and he is very adaptable. Tuk Atan often reminded the members of the group, including Pak Khalid, of what is and what is not allowed in Mak Yong performances, for instance, in the case of costume. Tuk Atan hung on to the rule that only the King and the Queen/Princess may wear kain songket (woven fabric interwoven with gold or silver ornamentation) during official occasions. Also, only the King/Cik Wang may wear a kris. This is not the case with Pak Khalid. When the organizers think that songket costumes and krisses are nice, although not worn at the proper occasion, Pak Khalid has no objections.

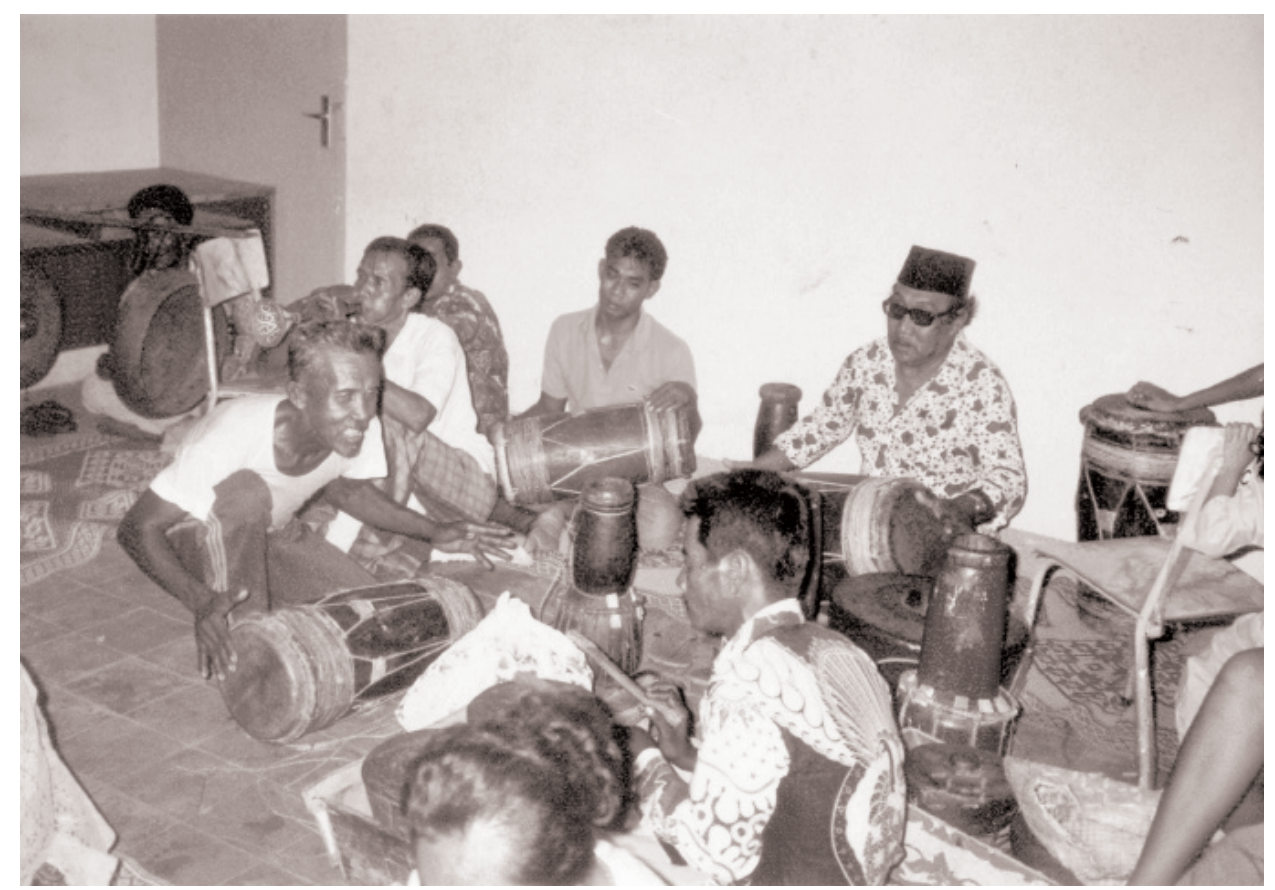

Illustration 3. Pak Khalid in his white t-shirt teaching the gendang; Photograph by the author, 1993.

As is the case in Kelantan, Riau Mak Yong thrived under the protection of the Riau Lingga Sultanate. When the Dutch and the English signed the London Treaty in 1824, the Malay region was divided and fell under two different rules: Semenanjung and Singapore under British and Melayu, subsequently known as Riau, under Dutch rule. The first Sultan to be appointed by the Dutch in Riau was Sultan Abdul Rahman Muadzam Syah. In 1911, when the then Sultan persisted in his opposition to the Dutch, the Dutch abolished the 
Sultanate. During this time Bintan Mak Yong still thrived, especially because of the inter-insular (for that time read: international) trade which thrived as well. A saying often heard among Mak Yong players when I interviewed them in the 1990s was kami bisa hidup dari ber-Mak Yong justru waktu ringgit dan dolar [dolar Singapura, present author] masih ada; kami tidak main hanya pada hari Jumat dan di bulan Puasa. (We could live from performing Mak Yong especially when the ringgit and the Singapore dollar were still in use and we did not only perform on Friday or during the fasting month). In the memory of the population, Mantang Arang used to be a thriving trading region. During the Riau Lingga Sultanate, Mantang Arang was the domicile of the High-court Judge, and Penyengat was the residence of the Young King (Raja Muda).

\section{REVITALIZATION OR RECONSTRUCTION?}

During the 1990s, when Tuk Atan and Pak Khalid were asked to perform just one episode of a Mak Yong story, they both said that Mak Yong no longer existed. When I asked about actors and supportive players, they answered that they were also no longer around, but that, if I planned to find them, I would have to look for them all over the islands because they had gone all over the place and never performed Mak Yong anymore. Tuk Atan and Pak Khalid both looked unhappy when they gave this answer to my questions about Mak Yong.

I was almost at my wit's ends. At the time, I was sent by LIPI (Lembaga Ilmu Pengetahuan Indonesia, the Indonesian Institute of Sciences) to investigate the social-cultural potential of the Riau Archipelago, especially Batam and Bintan. I decided to stay for a while in Kampung Keke, East Bintan, and in Matang Arang merely to investigate the reasons for the absence of Mak Yong. I visited the Mak Yong players Pak Khalid and Tuk Atan who lived on two different islands. Often I had to wait for weeks before I could meet a Mak Yong player because he had just gone out to sea and had not yet returned. I asked them all sorts of questions about Mak Yong and about their experiences in performing it and I even asked them if they were willing to perform again when the occasion arrived. In general they were happy to say that they would love to perform provided there was money for "those at home" (they meant money to sustain their wives and children) when they went out to perform Mak Yong. Women were in general also ready to join. Transportation proved to be the only problem.

Invigorated by a new spirit and supported by the local district chief, LIPI, and the Seroja Foundation, ${ }^{2}$ I finally succeeded in bringing together all the remaining Mak Yong players in the Balai Kajian Sejarah dan Nilai Tradisional,

2 In order to revitalize Mak Yong in Kepri, on 15 August 1976 a foundation was founded, chaired by a local high-ranking civil servant. Its members were Mak Yong seniors. From the eight original members only Pak Khalid is still alive. The foundation had the objective to protect and to support Mak Yong but unfortunately it was unable to succeed in the creation of a Mak Yong inheritance as they had expected. One of the trainers in the foundation subsequently founded the Sanggar Kemajuan Mak Yong in 2008. 
Departemen Pendidikan dan Kebudayaan (Centre for the Study of History and Traditional Values, Department of Education and Culture), now the Balai Pelestarian Sejarah dan Nilai Tradisional, Departemen Kebudayaan dan Pariwisata (Centre for the Preservation of History and Traditional Values, Department of Culture and Tourism) to restart training with Tuk Atan and Pak Khalid. In order to be able to keep them for one week at the Centre (especially for the male performers) we needed not only funds for their training, but also money to compensate them because they could not fish or work on their land for two weeks and we had to leave money behind before they were willing to come to the centre to perform. We also needed quite some money for interinsular transportation.

From the meetings at the Centre during one week we learned what was needed to revitalise Mak Yong, which had been dormant for all those years. ${ }^{3}$ The performers proved to be for the most part musicians. Two among them, Pak Gani and Pak Dolmat, aided the musicians (with the exception of the gendang and the gedombak) but also played the characters of Awang Pengasuh and Inang Pengasuh, two important characters in the plays next to the King and the Queen. Tuk Atan acted as trainer and he directed the story while Pak Khalid directed the play. Apparently, we were still in need of performers for the King, Queen/Princess, and the Ladies in Waiting, as well as members of the choir. Mak Wet acted as the trainer for the female parts. During the heydays of Mak Yong, Mak Wet acted the leading part of Cik Wang or of the King. Apart from performers, we also needed costumes and props in order to be able to perform. After a second one-week training session in Mantang Arang, finally, on 3 August 1991, a performance was staged in Mantang Arang. It was recorded on video and music cassette. One of the goals of the performance was to halt Riau Mak Yong's demise and also to be able to record it in its entirety. Another objective was to build up the spirit and the awareness of the holders of this rich cultural asset; Mak Yong is one of the constituents of the Malay identity especially of the local community but also of the Melayu (Riau) community in general. The performance also aimed at attracting the attention of the local community to their Malay cultural heritance of which they had heard but had never witnessed.

The performance was successful but there was also a troublesome event we only learned of when the performance was about to start. Tuk Atan refused to perform while his sons and his wife did appear urged to do so by Tuk Atan to ensure that the performance would be held. Tuk Atan's absence enraged the District Head and the Chairperson of the Seroja Foundation ${ }^{4}$ who both had sponsored the performance. Tuk Atan was said to be "fretting", to be a bad teacher, and to be disrespectful of their opinion. He persisted in his refusal to be involved because the performance violated Mak Yong principles. The attire that was used was in his view not truly Malay. The performers wore

3 The last performances that were recorded were sponsored by the Directorate of Arts in 1975 in Mantang Arang and by the Jakarta Art Board in 1982 in Penyengat, Bintan.

4 As mentioned above, he held the highest position in the local regional institution. 
dress à la Malaysia that was in fashion at the time. He was also opposed to the use of the word beta ("I") as it was not a Malay word. The last thing he could not agree with was that Wak Perambun, who is not a King, wore a kris. It just so happened that Pak Khalid played Wak Perambun and he thought that wearing a kris was perfectly all right.

Tuk Atan's absence changed a number of aspects of the performance. The title of the play that was to be staged changed from Raja Johan Nyaya to Wak Perambun, a story Pak Khalid had created based on a story from Malaysia and which was known in Patani under the name Raja Lak Kenarong. Pak Khalid had created the special character of Wak Perambun who was not in the original Raja Lak Kenarong story. Apart from changes to the story, some changes were also made in the musical accompaniment, which under Pak Khalid's direction was louder and more dynamic than under Tuk Atan's direction. The gedombak were also not used because Tuk Atan had taken the instruments home. He also owned the other musical instruments and the masks that were used in the performance, which he had inherited from Mak Ungu, but he had allowed the group to use them.

After the performance, the relation between the Mak Yong performers, especially between Pak Khalid and Tuk Atan and me became increasingly good. Bit by bit, confidence had grown among them that the Mak Yong was not only the object of a governmental project to generate money, but that the effort really was intended to invigorate their cultural legacy. Notwithstanding the tension between Tuk Atan and Pak Khalid and therefore between the members of their groups, slowly a new excitement about their Mak Yong involvement emerged as it was clearly something special that set their kampong apart from other kampongs and which made them more special than other people. In addition, the local authorities became more interested, from the Village Head up to the Regent of East Bintan. They started to talk of the Mak Yong as a token of the level of their cultural involvement. They also gave tangible support by providing Tuk Atan and Pak Khalid with special facilities. For instance, they no longer had to pay for electricity while administrative hassles such as arranging for identity cards, real estate tax, and vehicle registration cards were made much easier. Tuk Atan, who was also famous as a spiritual figure found himself increasingly often visited by guests, including local civil servants, for consultation and to ask for medicine or other sacral means.

\section{MAK YONG PERFORMANCE IN JAKARTA}

When efforts to halt Mak Yong's demise continued by also involving wider society outside the Malay community, the technical aspects of the preparations had already become much easier than they were during the first performance. Therefore, when Mak Yong was invited to perform in Taman Ismail Marzuki in Jakarta as part of the activities of the Seminar and Festival Tradisi Lisan from 9-11 December 1993, the Mak Yong community enthusiastically accepted. Financial aid was provided by the Governor of Riau Province (which at that time was still united with Island Riau) who immediately made sure that the 
group could depart for Jakarta. The Bintan Regional Government, the Seroja Foundation, and Malay adat figures joined forces to provide tangible aid as well, the more so since they learned that the organizing team would bear the costs for their stay in Jakarta and would also provide each performer with an honorarium. ${ }^{5}$ This time the training lasted for two months under the guidance of two well-known artists from Riau, B.M. Syamsudin and Khaelani, the head of the Regional Arts Department.

The group of performers that was being prepared for their performance in Jakarta was differently composed than the group that had performed in Mantang Arang in 1991. The training was now more directed to the players' own capabilities and capacities. For instance, the gendang player was now someone who really could play the instrument and not someone who was just playing around. The same was true for the performers of specific characters. The Awang Pengasuh in the Mak Yong play is an important character because he is the one who carries the story and thus a performer was sought who was really into the role. In the past, Pak Khalid usually performed the role, but of course, Pak Khalid could not play it now because his advanced age prevented him from moving around a lot on stage and his speech was no longer always very clear. He now acted as trainer for the Awang Pengasuh and the Inang Pengasuh roles, especially their dialogues and movements. The female role of Inang Pengasuh is usually played by a man and Pak Dolmat, an older member of the Mantang Arang Mak Yong group who had been playing Mak Yong since the 1950s and who had already performed the role of Inang Pengasuh before, could still act it. Mak Wet could no longer perform the role of Cik Wang/King, usually performed by a woman, for similar reasons mentioned for Pak Khalid. A new performer had to be found who was to be trained by Mak Wet. For a picture of Mak Wet performing a specific dance see Illustration 4 .

Also for the Princess, a new performer had to be found because the person who usually played the role no longer lived in Bintan. In all, the players consisted of musicians and actors (who enacted the dialogues, songs, and dances) who were old hands as well as youngsters who had just started to learn how to perform Mak Yong. The youngsters did not come from outside the Mak Yong community but appeared still to be closely related to the old Mak Yong generation. In this set-up, the composition of the Mak Yong group almost resembled the old situation when the community still thrived. The gendang and gedombak players are the most important in the Mak Yong group. Usually they also act as the leaders of the group and as its bomoh (spiritual shaman-like figure) whose task is to enact the opening and closing rituals (buka tanah and tutup tanah) of a performance. In fact, the rebab is more important than the gendang and the gedombak, but it had not been played in the Bintan Mak Yong community for a long time. The second most important are the King/Cik Wang and the Awang Pengasuh. The other musical performers and

The organizing team consisted of the Nusantara Oral Tradition Project (present day Asosiasi Tradisi Lisan/Oral Traditions Association), supported by the Ford Foundation, Kompas, Yayasan Obor Indonesia, KITLV, and the Lontar Foundation supported by AT\&T. 
players are not very high in status. The honorarium provided to the player reflected this.

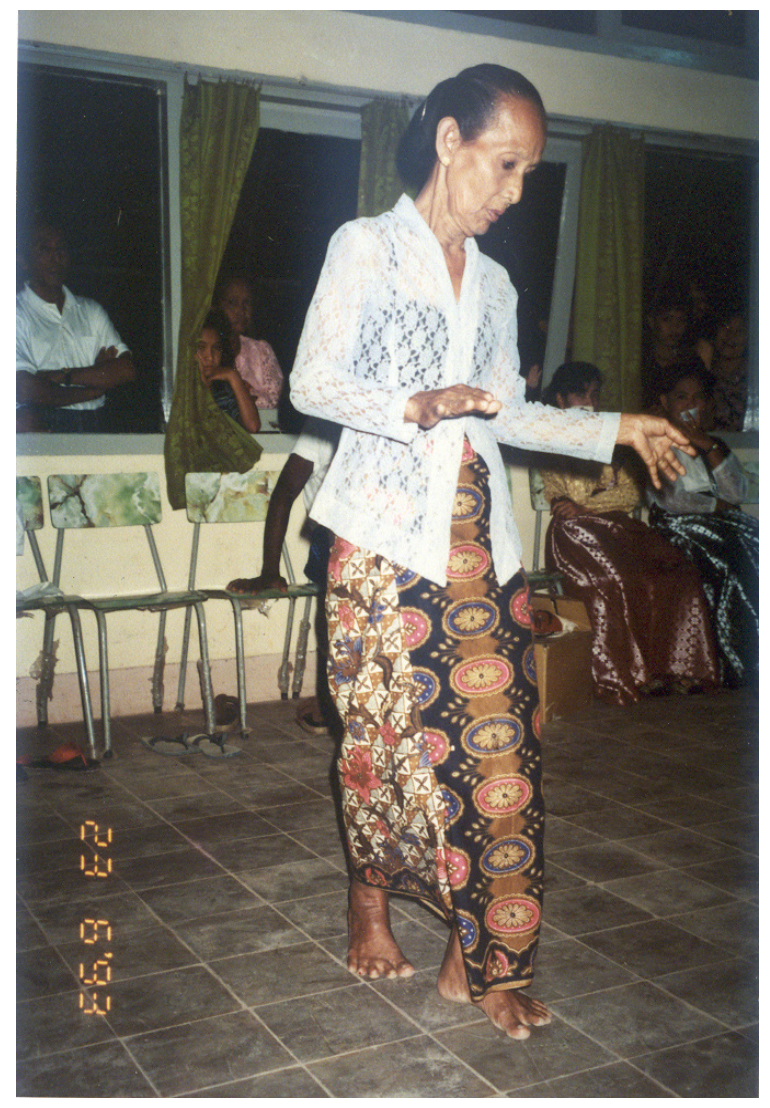

Illustration 4. Mak Wet, the prima donna of the secondgeneration Mak Yong players during training when she was demonstrating one of the movements in the Mak Yong; Photograph by the author 1993.

In order to approach an ideal performance, B.M. Syamsudin strongly supported the suggestions of the two Mak Yong figures in the choice of the players, their training, and the choice of story to be performed. With this in mind, Said Parman, who was to play the Awang Pengasuh role was brought in from Pekanbaru. He worked at the Cultural Office and had studied at the Indonesian Art Institute in Yogyakarta, Java. He had joined the Mak Yong revitalization program organized by the Jakarta Art Office in Penyengat, in 1982. At the moment (2010), Said Parman is the Head of the Manpower and Social Affairs Office of the City of Tanjung Pinang, and after the 1982 training, Pak Khalid and Tuk Atan considered him talented to play the Mak Yong. For this reason, he was specifically chosen and trained to play the role of Awang Pengasuh. He succeeded very well in this important role in the performance. He was coupled with Kadar Rusmiani, a relative of Tuk Atan who played the Cik Wang/King role. Another important role is that of Inang Pengasuh who was played very well and successfully by Pak Dolmat from Mantang Arang. He was accompanied by a girl, played by Rodiah, Rusmiani's younger sister. In addition, both their parents joined the performance. Their father was one 
of the musicians and their mother was one of the ladies-in-waiting and part of the choir.

The performers alternatively trained at Tuk Atan or Pak Khalid's house and they also spent the night there. For people from Keke and Mantang Arang this was not a problem, but for someone who did not originate from these places, such as Said Parman, some additional remarks need to be made. Although he is Malay and originates from Pulau Lingga, he had never envisioned that he could join the Mak Yong group and that he had to stay with the two Mak Yong maestros. He also had no idea that in order to train for the Mak Yong he had to "live in" for two months. As said above, Said Parman had joined the Jakarta Art Offices' revitalization program in 1982 but then he and others had studied the Mak Yong without having to stay with the Mak Yong community. At that time, they stayed in Pulau Penyengat and both Pak Khalid and Tuk Atan were brought over to Penyengat to train them under the tutelage of the Jakarta Art Office.

The training system I used to prepare them for their Mak Yong performance in Jakarta was indeed different from the system we had used previously. I purposefully asked the candidate performers to "live in" with the Mak Yong community so that they could learn to grasp the Mak Yong "spirit" really well. They were also expected to be able to grasp all the inner movements that were expressed in the outer movements of the dances, the songs, and the dialogues. They were expected not only physically to imitate what they were taught, but also to catch the depth of the expressions used by the Mak Yong figures who trained and helped them. The dialogue is equally important and has to be memorized because the language that is used during Mak Yong performances indeed differs from ordinary Malay. Many Malays themselves also do not understand the dialogues used in Mak Yong. The training and its accompanying "live in" program resulted in an almost perfect performance and may be said to have been the best Riau Mak Yong performance to date. Performers, such as Said Parman, also repeatedly expressed their satisfaction with the training. Up to now, he is still convinced that living with the Mak Yong community had made him truly understand this art tradition.

The performance in Jakarta also featured the most complete musical accompaniment ever to have been performed by the Keke and Matang Arang communities. It was complete in the sense that not only the musical instruments, but also the musicians who played them were of the highest quality. The serunai was played by the one remaining serunai player at the time, Pak Senen (see Illustration 5). He was especially brought in from Pulau Kasu in Batam to the Keke and Matang Arang communities. He left his work in the fields for two months and joined to follow the Mak Yong training sessions before the group left for Jakarta. The photograph below depicts Pak Senen while he was training the Mak Yong group at Tuk Atan's place.

The two performances within a time span of three years revived the memories of the Mak Yong community of their cultural inheritance. For them, having performed in Jakarta was a very important experience, especially in 
view of their self-esteem because they possess something special and that they were taken overseas to introduce what they have to other communities with other performing arts. Twenty groups joined the 1993 festival and there were about 200 people who discussed the Mak Yong in a forum during the seminar. When they returned to Bintan, invitations to perform the Mak Yong came in, both for official district celebrations as for community festivities around Bintan. Their self confidence started to increase and grew even more when a group of researchers arrived under the leadership of Philip Yampolsky, an American ethnomusicologist who came especially to record the Mak Yong. Sponsored by the Smithsonian Institute he recorded a number of specific Mak Yong songs, including the Betabek (the song that opens a performance), and the Cantik Manis (the closing song of a story) for the series Seri Musik Indonesia. The recording, with songs from other regions in the Melayu area were published in the form of a music cassette and CD at the end of 1996.

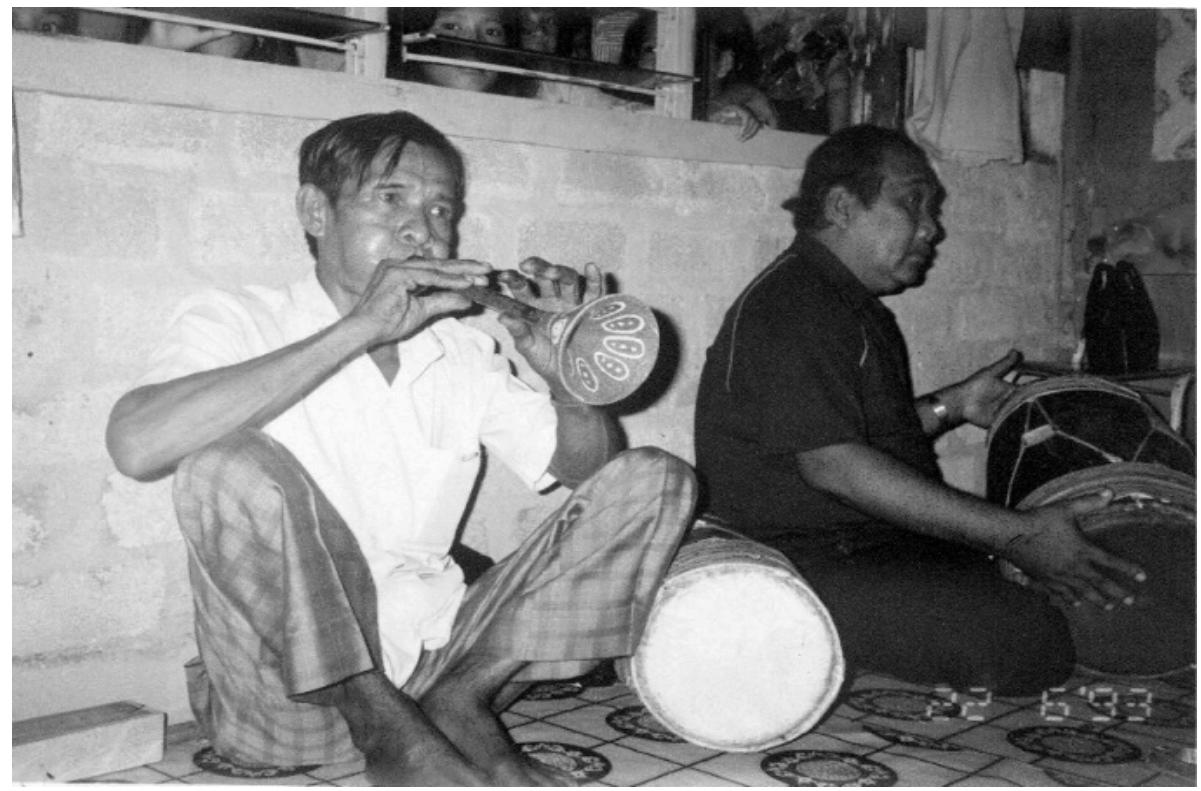

Illustration 5. Pak Senen plays his serunai; Photograph by the author 1993.

\section{REVITALIZATION OR LENDING SUPPORT TO TRADITIONAL SOCIETY}

It looks like the gradual process that has been proposed in the discussion of the Malay oral tradition oversteps the era of literacy. The question I posed above was "Reconstruction of revitalization"? I purposefully turned the question into a title in order to attract attention to the issue whether there is a difference between the terms or that one follows the other. From our exposition above, we may draw the conclusion that there is a fuzzy border between both as between the different colours in a spectrum and that there is some sort of grey area between them. This means that when we make a reconstruction, we are simultaneously involved in revitalization. Reconstruction is possible when the bearers of a tradition are apparently still in the dark. It is as if "the 
sleeping voices" sketched above were shattered over various islands and could emerge, or be made to emerge to the surface when attempts to revitalization were made. The problem is, how, and in what way can we turn the actual "sleeping voices" of the Mak Yong into "the singers of messages".

If, at some point, a researcher discovers that the tradition he is looking for proves to be no longer there, should he or she try to reconstruct that tradition so that it can be studied, or should he or she simply abandon the subject and consider it something of the past and no longer relevant. Is it irrelevant because he or she thinks that society no longer needs it and according to functional theory, when no longer needed means that the tradition may be ignored. If I had taken this decision in the 1990s, I would surely never have arrived at the certainty that Mak Yong is so important in the live of the Malays.

In its heyday, Mak Yong was considered a palace art (Achmad 1995: 7). Experts on Mak Yong from Kelantan and Patani came to the same conclusion. It may indeed be the case that Riau Mak Yong thrived in the Kingdom of Riau Lingga after the London Treaty of 1824 was put into force. However, Riau Mak Yong as studied today is no longer an exclusive performance for the palace or the aristocracy and directed at certain people only, but has become a form of entertainment for society in general (Pudentia 1992: 118). Nevertheless, it seems that Mak Yong no longer seems to have the same appeal as other popular art forms like dangdut, solo organ, and television. On the other hand, at the moment, Mak Yong does attract civil servants as related above in order to position themselves as cultured figures with a taste for high culture. For this kind of interest, it is indeed worthwhile to organize a Mak Yong performance and other popular performing art forms.

Mak Yong will always require a special program in order to manage it. Art traditions like the Mak Yong stem from the oral world and without considerable support will be unable to compete with other kinds of popular culture and art forms from the phase of secondary orality (to borrow Ong's term [1982]). In order to ensure that Mak Yong performances remain part of actual life in the Riau Islands, various programs have been executed. The Oral Traditions Association, as one of the foundations with a special interest in Mak Yong, has executed an intensive revitalization program and with the help from the Ford Foundation has provided extensive support to the Mak Yong society. The reason for this very modest revitalization was that society still needs Mak Yong as a symbol of its identity. Based on my five-year long research, I leaned how clearly Mak Yong has encouraged the Keke and Mantang Arang groups to re-perform it and to discuss it as part of their daily life. They have various traditional art forms, but Mak Yong is always mentioned as prestigious and as having added value.

THE FIRST STAGE OF REVITALIZATION

Revitalization was executed in three consecutive phases: introduction, 
strengthening, and development. ${ }^{6}$ With generous support from the Ford Foundation, all three phases were concluded successfully. At the start of the revitalisation, its limitations and the patterns to follow had not yet been set. Adopting a humanistic approach using the most natural way of support possible and devoid of any outside pressure, the community was assisted to meet its own expectations regarding Mak Yong. Pak Khalid, for instance, because he is a professional and he likes to teach and to transfer his knowledge to younger generations, asked for the implementation of a training program for the children in Keke to help realize his dream that Mak Yong would survive into the next generation. Performers such as Pak Dolmat (Inang Pengasuh) and Pak Gani (a musician) had very modest desires. They simply wanted to continue to perform Mak Yong as long as there was money for their families when they performed it. Young performers such as Rodiah's only fear was that her work in a factory in Batam might be in danger if she often performed Mak Yong. These kinds of specific technical matters can constitute a serious hindrance in the revival of Mak Yong if no support is provided to settle these issues. Therefore, during the first phase, introductions were provided not only for the performers and their supporters, but also to civil servants, society figures, and entrepreneurs. In the initial stage, when they had become aware that Mak Yong was part of their identity, some people were at first pessimistic. One of the reasons was that the Mak Yong performers form a marginal community in the Riau Islands. They are a community of small fishermen, plantation workers, and factory labourers. Only Tuk Atan stood out for his supernatural capabilities that were well-known in the Bintan region. It was initially difficult to convince the people that their art tradition was valuable. It only managed to attract attention, as has been described above, after the efforts of researchers of prestigious government institutions (LIPI and University of Indonesia) succeeded, the first performance in Mantang Arang had proven a success, and after the second performance in Jakarta during an international rather than national event, and even earlier when foreigners had started to look for Mak Yong. Intensive contacts were continued while the continuity of the performances was guaranteed by lending support to people who wanted to invite Mak Yong players to perform during their festivities or by offering Mak Yong performances to relevant groups in the Bintan region.

\section{THE SECOND STAGE}

The second stage was executed after a review had been made of the hindrances Mak Yong performers encountered and which had a great impact on their performances. Because of their personal circumstances and their economic conditions, they were easily provoked by people who wanted to use Mak Yong for their own interests. The following happened, for instance, just before

6 The revitalization did not always occur in this sequence. It happened that also elements of the second phase found their way in the first phase and so on. What is meant here are the main activities that gave their name to the focus of each phase. 
the group was to perform in Jakarta for a second time. After two months of training, Pak Khalid excused himself at the very last moment before departure to Jakarta. The issue was actually rather simple but seriously burdened Pak Khalid. He could not deal with the gossip and the complaints from his village head because one of the players, who happened to be a close relative of the village head, was excluded from joining the group to Jakarta whereas the village head had often assisted Pak Khalid during the training. This shocked the performers. Pak Khalid was a trusted person and very important in the performance. He played the gendang together with Tuk Atan who played the gedombak. This issue was settled. Nevertheless, tensions remained among the Keke and Mantang Arang groups because his outstanding quality in directing performances made the Mantang Arang community overconfident while the Kijang community adopted the same attitude because Tuk Atan was the most important mucision. Both groups therefore thought they were the best and both did not appreciate or accept the claim to superiority of the other. This tension proved to remain for a long time to come although efforts were made to unify them in one performance. Even after Tuk Atan passed away three years ago, the tension among the groups was not resolved.

Tensions between the Keke and Mantang Arang groups mounted. Initially, there were only tensions between Tuk Atan and Pak Khalid but after a while there were also tensions among the members of both groups. Thus, efforts to combine them in joined performances were halted. Both groups actually did have their own merits. The Mantang Arang group was strong in the stories as they were made by Pak Khalid and strong in the characters of Awang Pengasuh, Inang Pengasuh, and the Princess. The Keke group was strong in music, singing, and the figure of Cik Wang. However, because nobody was able to pacify them, including the Regent himself who had asked for a joined performance to enhance Kepri's prestige by staging a Mak Yong performance to give a display of all its excellent qualities, efforts for joint performances were discontinued. Formally, nothing seemed to be wrong. Tuk Atan and Pak Khalid even praised and supported each other but during rehearsals and performances it became apparent that combining them both was impossible.

\section{THE LAST STAGE}

The last stage of development was executed by providing the Mak Yong groups with three different repertoirs, one for research, one for performances during cultural events, and one for performances for tourists in hotels or during other, open occasions. The performers were divided into two classes. A film documentary was made to record all the movements and the dialogues of the Riau Mak Yong. The Bintan Resort in Lagoi had offered the Mak Yong group a three-month contract to perform. It was not executed because the group was unable to offer a tourist repertoire to be performed by a smaller group. If the honorarium they would receive would be used proportionately and the group would remain large, the amount each player would receive 
would be insufficient. This challenge still has to be met. Although there are risks, entering Mak Yong into the tourist industry is unavoidable if Mak Yong is to survive and a special strategy has to be devised to ensure that Mak Yong can prepare itself.

The tensions between Tuk Atan and Pak Khalid were interesting to witness. They actually boiled down to the tension between the oral world as represented by Tuk Atan and the literate world as represented by Pak Khalid. In general, the players preferred to be trained by Pak Khalid because he was more clear and consistent than Tuk Atan who was hard to follow and each time wanted something else. Pak Khalid was indeed a gifted storyteller and he often wrote stories and dialogues, whereas Tuk Atan was a gifted musician who often made new musical arrangements. This made it hard for those who had just started to play the musical instruments used in Mak Yong. Pak Khalid also was easygoing and accepted requests from outside, for instance in matters concerning costumes and props as mentioned above, which Tuk Atan could not, or only with great difficulty, accept.

\section{CLOSING REMARKS}

We have discussed the importance of revitalization for the survival of the Mak Yong and we have been faced by choices in which domain to put this art tradition. If it is to remain an oral tradition, it is almost impossible that new performers, who nowadays usually rely on written study materials, will be able to make their own new creations. In order to ensure its continuation, there is a strong need for the presence of a traditional art maestro.

In the Mak Yong case, after Pak Khalid and Tuk Atan's generation will be gone, a case of true orality will be gone as well. Their successors will have to learn by imitation and only after that they will be able to make their own creations. However, since they have little opportunity to perform, and because they have not yet been trained to play with a wide range of different characters because of the limited number of performances, the creative process also encounters problems.

As a product of culture, tradition is not something static innovations and developments cannot touch. A tradition invariably goes through transformations depending on the dynamics of society itself, both in relation to content, form, or both, and will constantly be replaced by new traditions considered more suitable to the existing situation, condition, and taste. In this view, traditions should not be seen as antiques that need to be preserved, or as something solid that has come down to us from times past that cannot and may not change, and have to be respected and preserved into posterity. This view elevates tradition, especially oral tradition as has been discussed in various studies, to a fixed position in history and by so doing deprives it of a chance to actualize itself in the present. It is high time a paradigm is created to view oral traditions as a force through which parts of our society can engage in a proper dialogue with other forces, especially with outside forces. This paradigm should be constructed departing from the view that oral traditions 
are a manifestation of the social-cultural activities of a community.

It is interesting to attach meaning to the dynamics that arise between the performing world, the "stage" world, and the world outside (supporters, audiences, researchers, owners of traditions, authorities, and others) in a paradigm that agrees that oral traditions are not merely works of art or performances, but also socio-cultural events that involve many intertwined issues. The way we look at traditions, including oral traditions, influences the way we manage them in order to ensure that they endure, for instance in the way Evans (2001) suggested. He showed that there is an interconnection between cultural sources, cultural policies, and the analysis of each of these factors in order to find the right kind of management planning. In order to decide on the right planning in connection with oral tradition we need to consider the following three factors: representation/ expression, resistance, and flexibility. For example, in Nias tradition there is the following saying: huku fona nira furi, lo moguna sa'oe (the tradition of the ancestors has to be abandoned so that adat can be replaced by religious regulation) or gofu hadia zalio matotoi, $d a^{\prime}$ o mofake (we use what we can easily pronounce). Festivities such as the Owasa (an enormous festivity not constricted to one clan/village and open to everybody) and Famoni (a four-day festivity in honour of the ancestors and in connection with the harvest) are seldom encountered anymore. Although there have been intercultural movements from the local churches since the 1970s, much that is considered incompatible with the new situation of the Nias people and their new conviction is no longer enacted. ${ }^{7}$ Nevertheless, although state laws and the church have stipulated marriage regulations, many girls still marry under age because they continue to abide by adat. The tension between tradition (read also: convention) and innovation or modernization, or between tradition and Governmental notions and "official rules" is always interesting to investigate. This article does not intend to say that tradition is much better or much more positive than law or any other teachings and also not to claim the opposite. Not everything that is represented in oral tradition can still be regarded as appropriate or functional in modern circumstances and therefore their demise is often not lamented. However, this does not mean that tradition is merely part of the past or should only be viewed as an inheritance that only needs to be preserved so that only for this reason preservation and documentation are required. Whatever the case, tradition is also part of our present-day existence and we can learn from it as it is, in a new packaging, or in a transformed way. Tradition may emerge in a new form and with a new function but it will remain in Hobsbawn and Ranger's words an "invented tradition". 8 As long as the "spirit" of this tradition is still felt and its presence known, in no matter what way it manifests itself, it can still be called traditionally based. Artists use many different ways to manage tradition: they use formulae; they construct traditional models; and/or they

7 These changes occurred after the II Vatican Council that pronounced a positive attitude towards cultural traditions as something that gave expression to Gods' wealth.

8 See Hobsbawn and Ranger 1989. 
transform them. ${ }^{9}$ Numerous ideas may come up about how to picture tradition or what is considered traditional. ${ }^{10}$

Based on our standpoint as discussed at the outset of this article, oral tradition is an important source of identity formation and it should be revitalized regardless of the problems, conditions, and restraints we are forced to face in order to do so.

\section{REFERENCES}

Achmad, Kassim. 1995. "Mak Yong teater tradisional Riau; Bentuk, perubahan, dan perkembangan". Paper, Seminar Mak Yong, Pulau Pinang, 9 September.

Akmar. 1993. "Kelantan ban on Makyong and Wayang Kulit stays", New Straits Times, 18 December.

Evans, Graeme. 2001. Cultural planning. London/New York: Routledge.

Feinstein, Alan. 1995. "Modern Javanese theatre and the politics of culture; A case study of Teater Gapit", Bijdragen tot de Taal-, Land-en Volkenkunde 151: 617-638.

Ghulam-Sarwar, Yousof. 1982. "Mak Yong; The ancient Malay dance-theatre”, Asian Studies Vol. XX: 108-121.

Hobsbawn, Eric and Terrace Ranger (eds). 1989. The invention of tradition. New York: Cambridge University Press.

Ong, Walter J. 1982. Orality and literacy; The technologizing of the word. London/ New York: Methuen. [First published 1977.]

Pudentia MPSS. 1992. Transformasi sastra; Analisis atas cerita rakyat "Lutung Kasarung". Jakarta: Balai Pustaka.

Sastrosuwondho, Soemantri. 1985. "Teater Mak Yong dan pengembangannya”. Paper, Pertemuan Ilmiah Kebudayaan Melayu, Tanjung Pinang, Riau.

Sheppard, Mubin. 1972. Taman indera. Kuala Lumpur: Oxford University Press.

Suki, Herani Khairani Bte Ismail and Ayup Ismail. 1978. Mak Yong dan wayang kulit: kumpulan essei. Kuala Lumpur: Kementerian Kebudayaan Belia dan Sukan.

Yampolsky, Philip. 2001. "Can the traditional arts survive, and should they?", Indonesia 71 (April). 